\title{
PSEUDOTAXIPHYLLUM SUBFALCATUM (PLAGIOTHECIACEAE, BRYOPHYTA) IN ASIA: ONE MORE SPECIES WITH AN ARCTO-TERTIARY DISJUNCTION
}

\section{PSEUDOTAXIPHYLLUM SUBFALCATUM (PLAGIOTHECIACEAE, BRYOPHYTA) В АЗИИ: ЕЩЕ ОДИН ВИД С ДИЗЬЮНКТИВНЫМ АРЕАЛОМ АРКТО-ТРЕТИЧНОГО ТИПА}

\author{
Olga M. AfoninA ${ }^{1}$, Sergei G. KAZANOVSKY ${ }^{2}$, Olga Yu. PisARENKO ${ }^{3}$, AlinA V. FEdOROVA ${ }^{4}$ \\ \& ELENA A. IGNATOVA ${ }^{5}$ \\ ОЛЬГА М. АФОНИНА ${ }^{1}$, СЕРГЕЙ Г. КАЗАНОВСКИЙ ${ }^{2}$, ОЛЬГА Ю. ПИСАРЕНКО ${ }^{3}$, АЛИНА В. ФЕДОРОВА ${ }^{4}$, \\ ЕЛЕНА А. ИГНАТОВА ${ }^{5}$
}

\begin{abstract}
Pseudotaxiphyllum subfalcatum, a species previously known only from North and South America, is found in herbarium collections from Asiatic Russia. Its identity is confirmed by molecular markers, and sequence data from GenBank also indicate the occurrence of this species in Japan. The description and illustration of Russian specimens are provided and a comparison of the three Pseudotaxiphyllum species currently known in Russia is given. Pseudotaxiphyllum elegans occurs in NW European Russia, Caucasus, Yakutia, and the Northern and Southern Far East; $P$. distichaceum grows in the Kuril Islands, and $P$. subfalcatum is found in Iturup Island (South Kuril Islands) and in the Baikal area of southern Siberia.
\end{abstract}

Резюме

Pseudotaxiphyllum subfalcatum, вид, который до настоящего времени был известен только из Америки, найден в гербарных коллекциях из азиатской России. Видовая принадлежность образцов подтверждена с помощью молекулярных маркеров; кроме того, данные по последовательностям ДНК из генбанка свидетельствуют о наличии этого вида в Японии. Приведены описание и иллюстрации российских образцов, а также диагностические признаки трех известных в настоящее время из России видов рода Pseudotaxiphyllum. Pseudotaxiphyllum elegans встречается на северозападе европейской России, Кавказе, в Якутии, на севере и юге российского Дальнего Востока; $P$. distichaceum найден на южных Курильских островах, а P. subfalcatum - на о. Итуруп (Южные Курилы) и в районе озера Байкал на юге Сибири.

KEYWORDS: phytogeography, disjunctions, mosses, molecular phylogeny, ITS, trnL-F

\section{INTRODUCTION}

The genus Pseudotaxiphyllum Z. Iwats. was segregated from Isopterygium Mitt. to accommodate species mainly with axillary propagules, lacking pseudoparaphyllia and having differentiated annuli (Iwatsuki, 1987). Seven species were listed by Iwatuki (1.c.), i.e. P. arquifolium (Bosch \& Sande Lac.) Z. Iwats., P. pohliaecarpum (Sull. \& Lesq.) Z. Iwats., P. densum (Cardot) Z. Iwats., P. distichaceum (Mitt.) Z. Iwats., P elegans (Brid.) Z. Iwats., P. fauriei (Cardot) Z. Iwats., and P. maebarae (Sakurai) Z. Iwats. Later two American species, $P$. homomallifolium (Redf.) Ireland and P. richardsii (E.B. Bartram) Ireland, were added to the genus by Ireland (1991). Ireland (1.c.). also submerged Isopterygium subfalcatum (Austin) A. Jaeger (de- scribed from the U.S.A. as Plagiothecium subfalcatum Austin) into synonymy with $P$. distichaceum (described from the Himalayas), thus extending the distribution of $P$. distichaceum into North America.

Subsequently, P. laetevirens (Dixon \& Luisier ex F. Koppe \& Düll) Hedenäs from Macaronesia was recognized at the species level (Hedenäs, 1992); P. falcifolium (Hook. f. \& Wilson) S. He from New Zealand was transferred to the genus from Homalia (He, 1997); and P. obtusifolium Z. Iwats. \& B.C. Tan from Taiwan and mainland China was described as new to science (Iwatsuki \& Tan, 2004). Pseudotaxiphyllum is currently treated as a member of Plagiotheciaceae based on molecular-phylogenetic data (Huttunen et al., 2013).

1 - Komarov Botanical Institute of Russian Academy of Sciences, Prof. Popov Str., 2, St. Petersburg, 197376 Russia - Poccия, 197376, Санкт-Петербург, Проф. Попова 2, Ботаническиий институт им. В.Л. Комарова РАН; e-mail: stereodon@yandex.ru

2 - Siberian Institute of Plant Physiology and Biochemistry, POBox 317, Irkutsk 664033 Russia - Сибирский институт физиологии и биохимии растений, a/я 317, Иркутск 664033 Россия; e-mail: kazan@sifibr.irk.ru

3 - Central Siberian Botanical Garden SB of RAS, Zolotodolinskaya 101, Novosibirsk 630090 Russia - Россия 630090 Новосибирск, Золотодолинская, 101, Центральный Сибирский ботанический сад CO PAH; e-mail: o_pisarenko@mail.ru

${ }^{4}$ - Tsitsin Main Botanical Garden, Russian Academy of Sciences, Botanicheskaya Str., 4, Moscow 127276 Russia - Россия 127276 Москва, Ботаническая 4, ГБС РАН; e-mail: alina777777@mail.ru

5 - Lomonosov Moscow State University, Faculty of Biology, Plant Ecology and Geography Dept., Leninskie Gory Str. 1-12, Moscow 119234 Russia - Россия, 119234, Москва, Ленинские Горы, д. 1 стр. 12, Московский государственный университет, биологический факультет, кафедра экологии и географии растений; e-mail: arctoa@list.ru 
Phylogenetic relationships and species delimitation within Pseudotaxiphyllum were addressed by Li et al. (2015). Their study of chloroplast and nuclear molecular markers and morphological characters of mainly East Asian specimens, with addition of some North American and European samples, resulted in the recognition of eight species within the genus. Four species listed by Iwatsuki (1987), i.e. P. aeguifolium, $P$. densum, $P$. fauriei, and $P$. pohliaecarpum were synonymized with $P$. distichaceum. At the same time, Li et al. (2015) distinguished the North American specimens referred to P. distichaceum from the East Asian collections of this species, referring the American plants to P. subfalcatum (Austin) X.Q. Li, Q. Zuo \& Y.F. Wang.

Until recently, only one species of Pseudotaxiphyllum, P. elegans, was known from the territory of Russia: it was reported from NW European Russia, Caucasus, Chukotka, Kamchatka, Magadan Province and Primorsky Territory (Ignatov et al., 2006) and subsequently found in Yakutia (Ivanova et al., 2018). One more species, P. pohliaecarpum, was reported from the Kuril Islands (Bakalin et al., 2009).

During the identification of unnamed herbarium collections kept in IRK, OA found one rather scarce specimen of Pseudotaxiphyllum from the Republic of Buryatia, collected in 2011 by SK, in the vicinity of Lake Baikal. Morphological characters of these plants, i.e. flattened foliage, cultriform leaves and propagules conspicuously clustered at the shoot tips, were in agreement with the circumscription of the North American plants of "P. distichaceum" (Ireland, 2014). The propagula shape (vermiform, 23 cells wide, with leaflets at the tips) also supported this identification. Since this specimen could be the first record of the American P. subfalcatum in Eurasia, testing with molecular markers was undertaken, which confirmed the identity of the Baikal specimen with the North American P. subfalcatum. However, in the course of this search, we also revealed one sample from Japan with the $\operatorname{trn} \mathrm{L}-\mathrm{F}$ sequence stored in GenBank, which is identical to P. subfalcatum, but not presented in the study of Li et al. (2015). Thus the total revision of Far Eastern Pseudotaxiphyllum herbarium collections was undertaken, with sequencing several samples, in order to elucidate the species composition of this genus in Russia. In species circumscription we follow Li et al. (2015).

\section{MATERIAL AND METHODS}

Pseudotaxiphyllum specimens from Russia were studied for nuclear ITS and chloroplastic trnL-F, as these markers were proved to be the most informative in pleurocapous mosses (cf. Huttunen et al., 2013), and moreover studied in many specimens of Pseudotaxiphyllum from Asia (Li et al., 2015).

Total genomic DNA was extracted from dry plants using the Nucleospin Plant Extraction Kit (MachereyNagel, Germany). Laboratory protocol was essentially the same as in previous moss studies, described in detail by, e.g., Gardiner et al. (2005).
Sequences were embedded in GenBank data, mostly from the Li et al. (2015) analysis. We selected specimens where both ITS and trnL-F were available, omitting mostly those where only one locus was known. One exception was made for a Japanese specimen where only $\operatorname{trn} \mathrm{L}-\mathrm{F}$ was known: it was included into the analyses due to its phytogeographical importance, as explained below in the Discussion section. Sequences where aligned by Clustal and modified manually using BioEdit 7.0 (Hall, 1999). Bayesian analysis of the ITS dataset was conducted in MrBayes (Huelsenbeck \& Ronquist, 2001) using the GTR+G model. It was run for 20000000 generations with sampling every 1000 generations, the chain temperature was set at 0.02 . The first $25 \%$ of sampled trees were discarded for the burn-in.

\section{RESULTS}

The molecular phylogenetic tree resolved Pseudotaxiphyllum elegans in a maximally supported clade sister to the rest of the genus, which has a rather complicated phylogeny. The latter clade has low support $(\mathrm{PP}=0.74)$ and is composed of two maximally supported clades. One includes only two specimens from SE China (Zhejiang and Taiwan), referred by Li et al. (2015) to P. distichace$u m$, and in the tree we use this name with the addition 's.l.'. Another clade performs the grade of (1) subclade of $P$. subfalcatum s.l.; (2) subclade of $P$. mayebarae; and terminal clade (3) of $P$. distichaceum (note that in Genbank $P$. distichaceum specimens are deposited under the name $P$. “pohliicarpum”). Subclade of $P$. subfalcatum s.1. (1) included one specimen from Japan, deposited in GenBank under the name P. pohliaecarpum ["P. pohliicarpum”']. Subclade 3 includes several nested clades with various supports, from low to maximal.

\section{DISCUSSION}

The obtained phylogeny is based largely on specimens used in the Li et al. (2015) analysis, thus the overall tree topology is almost the same and that thoroughly discussed already in that publication. We repeat that the species $P$. distichaceum in the present circumscription likely comprises a complex of cryptic species; however, it requires an additional study, as attempts of Li et al. (2015) to find morphological differences did not succeed. The distinct position of specimens from Zhejiang and Taiwan is especially enigmatic.

Specimens from Baikal Lake area and Iturip Island were found in the clade with P. subfalcatum, and moreover they are subidentical with a specimen of $P$. subfalcatum from North Carolina, U.S.A. Two other American specimens, from Maine and Pennsylvania, are slightly different molecularly, although they have no apparent morphological differences from the North Carolina specimen (according to their comparison by Allen and Atwood, letter of 16 October 2019). Japanese specimen QZJP85 ("P. pohliicarpum" in Fig. 1, GenBank accession HQ665374) has only $\operatorname{trn} \mathrm{L}-\mathrm{F}$ sequence, but it was resolved in $P$. subfalcatum-clade, because it has three 


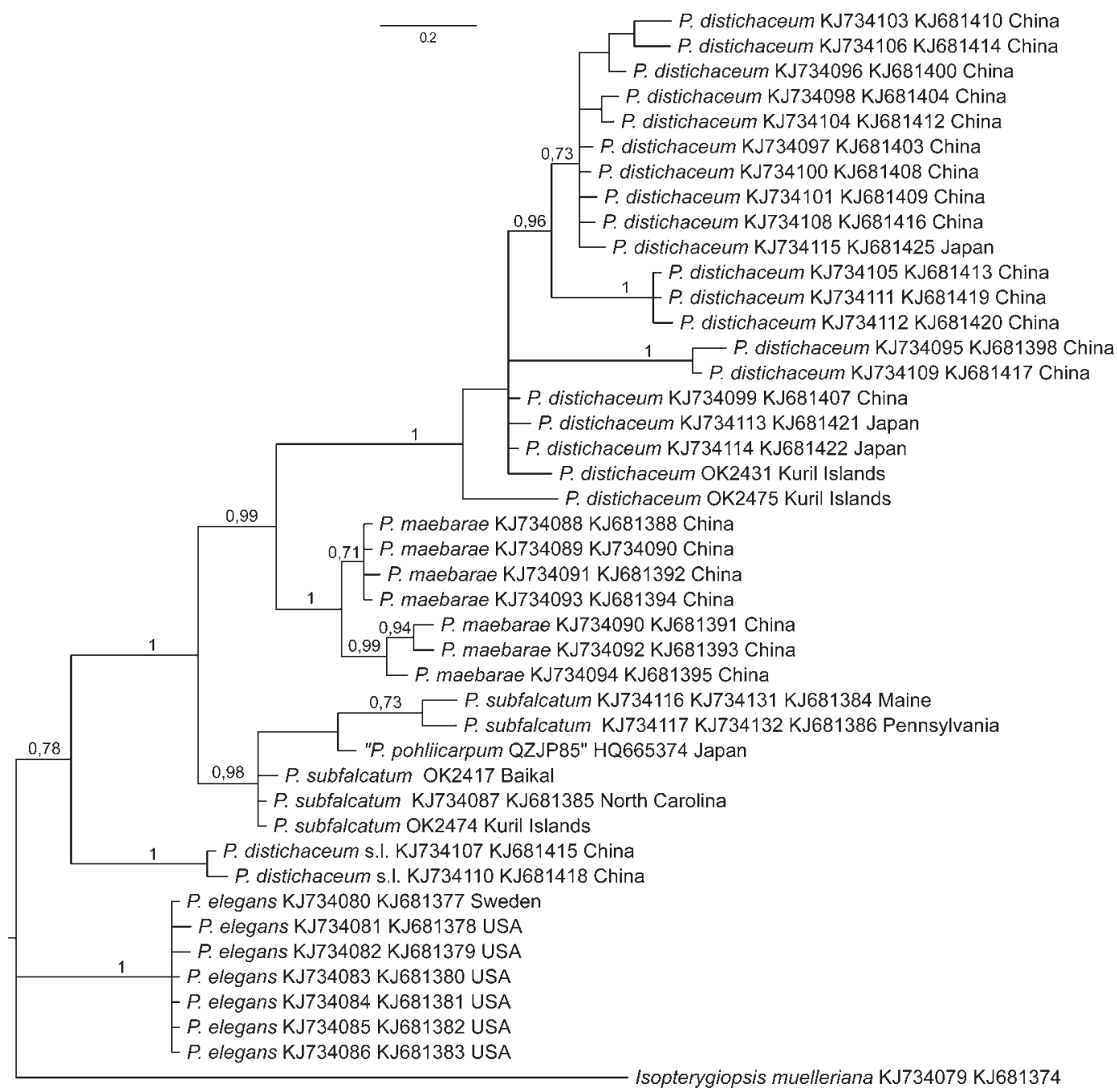

Fig. 1. Bayesian tree of Pseudotaxiphyllum inferred from nuclear ITS and chloroplastic trnL-F sequences. Names are given according to Li et al. (2015) and partly differ from names in Genbank. New sequence data are in Appendix 1. Posterior probabililities $>0,70$ are shown at nodes.

unique and two subunique substitutions which differentiate $P$. subfalcatum from all other species of the genus. One of our specimens of $P$. distichaceum from the Kurils (OK 2431) was also studied for trnL-F only, as its ITS was too heterogeneous, though several characteristic substitutions in its sequence clearly indicate its identity with another Kuril specimen, OK 2475.

Interestingly, the latter Kuril specimen of $P$. distichaceum (OK 2475) was collected in the same area where the Kuril's $P$. subfalcatum was found, though they were collected on slopes of different mountains, at different altitudes (500 and $150 \mathrm{~m}$ a.s.l., respectively), and apparently in places with different bedrocks. Furthermore, this specimen totally lacks propagules, and thus was included in our analysis to check its identity. This confirms the conclusion of Li et al. (2015) that the lack of propagules may occur in P. distichaceum, and the type specimen of this species also lacks them. Kuril specimen, OK 2475, is totally green, apparently because of the growth in deep shade (most Kuril specimens are at least partly cherry-red), and this might explain the underdevelopment of propagules.

In terms of biogeography, . subfalcatum is one more addition to the Arcto-Tertiary relic group of species, with the disjunction between East Asia and eastern North America (Schofield \& Crum, 1973; Schofield, 1988; Ignatov, 1993). Such species are more common in the easternmost part of Asia, including East China, Japan and Russian Far East, but some of them reach the Baikal Lake area, e.g. Brothera leana, Buxbaumia minakatae, Anomodon minor, and Pylaisiadelpha tenuirostris.

Although we did not see Japanese specimen (QZJP85), the GenBank accession HQ665374 rather clearly indicates that $P$. subfalcatum occurs in Japan, although the species is probably not common there (a number of collections studied in MW, MHA, LE and $\mathrm{H}$ did not reveal it). In the Kuril Islands P. subfalcatum was collected only once, whereas $P$. distichaceum is more common. 


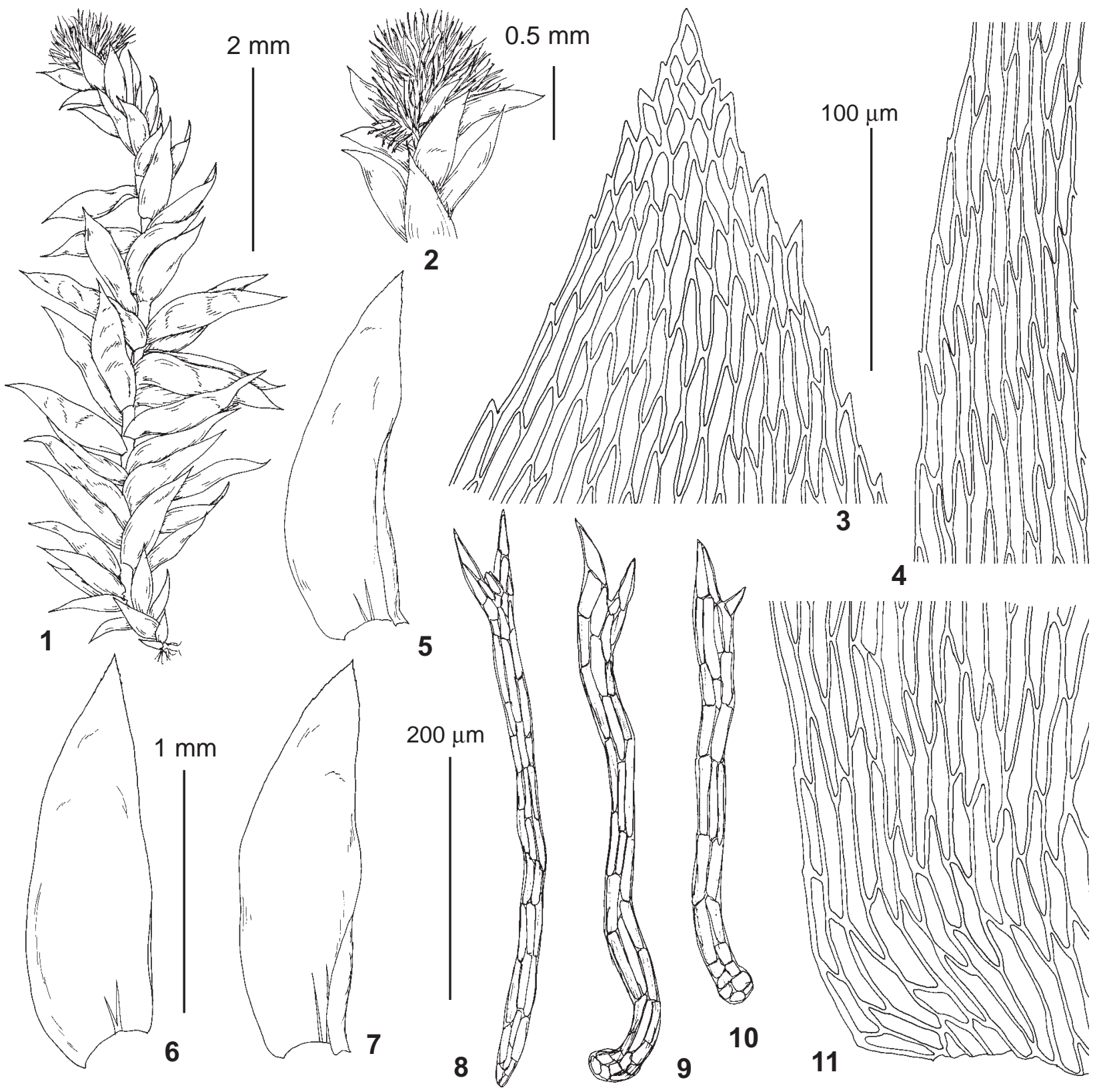

Fig. 2. Pseudotaxiphyllum subfalcatum (from: Russia, Buryatia, 9.VIII.2011 Kazanovsky s.n., LE, MHA). 1 - habit, dry; 2 shoot apex with axillary propagules; 3 - upper laminal cells; 4 - median laminal cells; 5-7 - leaves; 8-10 - axillary propagula; 11 - basal laminal cells. Scale bars: $2 \mathrm{~mm}$ for $1 ; 1 \mathrm{~mm}$ for $5-7 ; 0.5 \mathrm{~mm}$ for $2 ; 200 \mu \mathrm{m}$ for $8-10 ; 100 \mu \mathrm{m}$ for 3-4, 11 .

\section{TAXONOMY}

\section{KEY TO THE IDENTIFICATION OF PSEUDOTAXIPHYLLUM} SPECIES IN RUSSIA

1. Leaves \pm symmetrical, from ovate base abruptly or gradually narrowed into filiform acumen; axillary brood branches with leaflets along their bodies P. elegans

- Leaves asymmetrical, cultriform, acute at apex; axillary brood branches with leaflets restricted to their apices

.. 2

2. Axillary brood branches born in leaf axils throughout the stem, more than 3 cells wide...

P. distichaceum
- Axillary brood branches born in leaf axils only at shoot apex, $2-3$ cells wide. P. subfalcatum

Pseudotaxiphyllum subfalcatum (Austin) X.Q. Li, Q. Zuo \& Y.F. Wang, J. Syst. Evol. 53(2): 188. 2015. Plagiothecium subfalcatum Austin, Musci Appalach. 366[schedae 61]. 1870. - Isopterygium subfalcatum (Austin) A. Jaeger, Ber. Thätigk. St. Gallischen Naturwiss. Ges. 1876-77: 438 (Gen. Sp. Musc. 2: 504). 1878. - Pseudotaxiphyllum distichaceum auct. non (Mitt.) Z. Iwats. (Fig. 2 and 3: 9-12, 15).

Plants small to medium-sized, light green, glossy, forming flat mats. Stems simple or irregularly branched, complanate-foliate. Leaves 1.1-2.0 mm long and ca. 0.5 


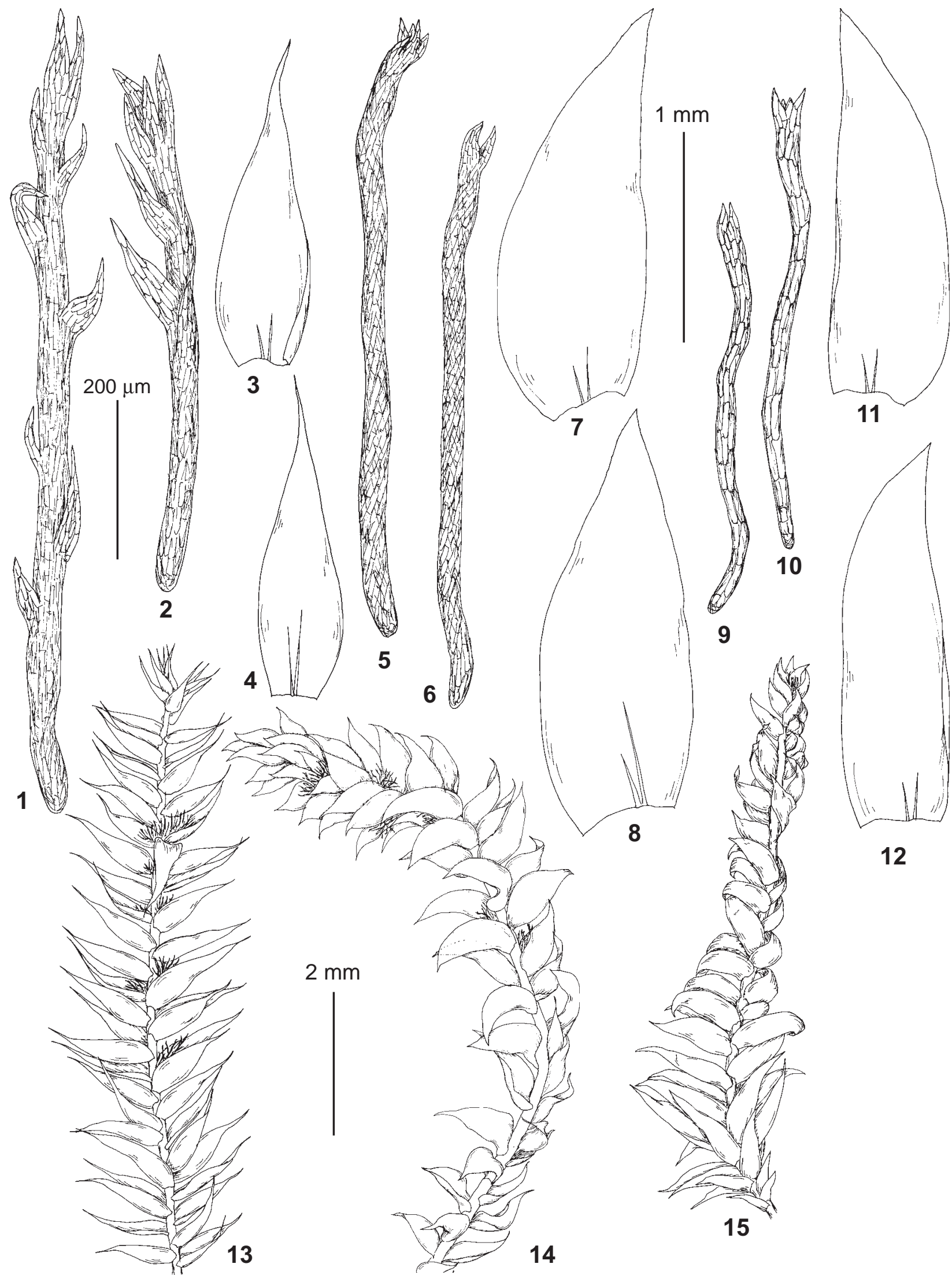

Fig. 3. 1-4, 13: Pseudotaxiphyllum elegans (from: Russia, Chukotka, Lavrentia settlement, 10.VIII.1969 Afonina s.n., LE); 5-8, 14: P. distichaceum (from: Russia, Kunashir Island, Ignatov 06-1697, MHA); 9-12, 15: P. subfalcatum (from: Russia, Buryatia, 9.VIII.2011 Kazanovsky s.n., LE, MHA). 1-2, 5-6, 9-10 - axillary propagula; 3-4, 7-8, 11-12 - leaves; 13-15 - habit, dry. Scale bars: $2 \mathrm{~mm}$ for $13-15 ; 1 \mathrm{~mm}$ for $3-4,7-8,11-12 ; 200 \mu \mathrm{m}$ for $1-2,5-6,9-10$. 
mm wide, spreading, often undulate, oblong to oblonglanceolate, asymmetrical, cultriforme, acute; margins plane or narrowly recurved at base, serrate at apex, below serrulate to mid-leaf; costa short and double; midleaf cells linear-flexuose, 50-75(-88)×7-8 $\mu \mathrm{m}$, at apex shorter, rhomboidal; alar cells not differentiated. Specialized asexual reproduction by axillary propagules (brood branches) usually present in leaf axils at shoot tips; brood branches numerous, $0.2-0.6 \mathrm{~mm}$ long, twisted-vermiform, 2-3 cells wide, with 1-5 acute, erect leaflets at apex. Gametangia not seen in specimen from Russia. [Dioicous. Sporophytes unknown.]

Specimens examined: RUSSIA: Republic of Buryatia, Kabansky Distr., Baikalsky Nature Reserve, right bank of Vydrinaya River, $51^{\circ} 25^{\prime} 38,1^{\prime \prime} \mathrm{N}, 104^{\circ} 54^{\prime} 21,0{ }^{\prime} \mathrm{E}, 565 \mathrm{~m}$ alt., SWfaced slope ca. $20^{\circ}$ with rock outcrops, mixed forest of birch, Siberian pine, spruce and fir with Bergenia crassifolia, 9.VIII.2011, Kazanovsky s.n. (LE, MHA). The plant was presumably collected on ledge of rock outcrop. Sakhalinskaya Province, South Kuril Islands, Iturup Island, Medvezh'ya Bay, $45.416^{\circ} \mathrm{N}, 148.826^{\circ} \mathrm{E}, 150 \mathrm{~m}$ alt., creek in the lower part of Nfaced slope of Medvezh'ya Mt., 15.IX.2015 Pisarenko op05831 (MW 9060912, duplicate from NSK).

Distribution and ecology. Until now, P. subfalcatum was known in eastern North America, as well as Central and South America; in N. America it occurs from Arkansas and Georgia to Ontario and Quebec, typically growing on moist cliffs of acid rocks, on ledges, and in crevices, sometimes on peaty soil in woods (Crum \& Anderson, 1981; Ireland, 2014). In Asiatic Russia it was also collected in shaded and rather moist environments, especially in Iturup Island, where this species grows on volcanic rocks along small stream covered with soil and moist debris. This creek runs on slope of old volcano covered by secondary vegetation formed after fire by Sasa sp. thickets and sparse trees of Larix kamtschatica; these thickets are so dense, that form a pipe-like corridor 2-4 $\mathrm{m}$ wide along the stream bed and making this space wet and shady.

Differentiation. Specimens of $P$. subfalcatum from Buryatia are similar to the widespread SE Asia $P$. distichaceum, in their asymmetrical, cultriform leaves with acute apices and twisted-vermicular axillary brood branches with apical leaflets. However, these plants of $P$. subfalcatum lack red pigmentation, which is often present in plants of $P$. distichaceum (e.g. in Russian collections from the Kuril Islands); in P. subfalcatum brood branches are born in the leaf axils only at the shoot apices, while in $P$. distichaceum the brood branches are present in the leaf axils along the whole stem; and the brood branches of $P$. subfalcatum are smaller and narrower, 2-3 cells wide, whereas in P. distichaceum they are longer and wider, 4-5 cells wide (Fig. 3).

\section{ACKNOWLEDGEMENTS}

We are grateful to Bruce Allen and John Atwood for providing information on the morphology of the American specimens of Pseudotaxiphyllum subfalcatum. The contribution of O. M. Afonina was carried out within the framework of the institutional research project "Flora of lichens and bryophytes of Russia and phytogeographically important regions" (AAAA-A19-119020690077-4). Molecular studies of A.V. Fedorova and E.A. Ignatova were supported by RSF18-14-00121. The contributions of S.G. Kazanovsky was supported by RFBR 18-04-00822.

\section{LITERATURE CITED}

BAKALIN, V. A., V. YA. CHERDANTSEVA, M. S. IGNATOV, E. A. IGNATOVA \& T. I. NYUSHKO. 2009. Bryophyte flora of the South Kuril Islands (East Asia). - Arctoa 18: 69-114.

CRUM, H. A. \& L. E. ANDERSON. 1981. Mosses of the Eastern North America. Vol. 2. - Columbia University Press, New York. pp. 664-1328.

GARDINER, A., M. IGNATOV, S. HUTTUNEN \& A. TROITSKY. 2005. On resurrection of the families Pseudoleskeaceae Schimp. and Pylaisiaceae Schimp. (Musci, Hypnales). - Taxon 54: 651-663.

HALL, T. A. 1999. BioEdit: a user-friendly biological sequence alignment editor and analysis program for Windows 95/98/NT. - Nucleic Acids Symposium Series 41: 95-98.

HEDENÄS, L. 1992. Notes on Madeiran Pseudotaxiphyllum, Brachythecium and Rhynchostegiella species (Bryopsida). - Nova Hedwigia 54: 447-457.

HE, S. 1997. A revision of Homalia (Musci: Neckeraceae). - Journal of the Hattori Botanical Laboratory 81: 1-52.

HUELSENBECK, J. \& F. RONQUIST. 2001. MRBAYES: Bayesian inference of phylogenetic trees. - Bioinformatics 17: 754-755.

HUTTUNEN, S., M. S. IGNATOV, D. QUANDT \& L. HEDENÄS. 2013. Phylogenetic position and delimitation of the moss family Plagiotheciaceae in the order Hypnales. - Botanical Journal of the Linnean Society 171(2): 330-353.

IGNATOV, M. S. 1993. Moss diversity patterns on the territory of the former USSR. - Arctoa 2: 13-47.

IGNATOV, M. S., O. M. AFONINA \& E. A. IGNATOVA. 2006. Checklist of mosses of East Europe and North Asia. - Arctoa 15: 1-130.

IVANOVA, E. I., E. A. IGNATOVA, V. G. ISAKOVA, I. A. BALAKIREV, O. I. KUZNETSOVA \& M. S. IGNATOV. 2018. Moss flora of Ust-Nera region in the upper course of Indigirka River, East Yakutia. Arctoa 27(1): 18-28.

IWATSUKI, Z. 1987. Notes on Isopterygium Mitt. (Plagiotheciaceae). Journal of the Hattori Botanical Laboratory 63: 445-451.

IWATSUKI, Z. \& B. C. TAN. 2004. Pseudotaxiphyllum obtusifolium, a new species of Hypnaceae (Musci) from China. - Novon 14: 75-78.

IRELAND, Jr., R.R. 1991. A preliminary study of the moss genus Isopterygium in Latin America. - Caldasia 16(78): 265-276.

IRELAND, Jr., R.R. 2014. Plagiotheciaceae. - In: Flora of North America Editorial Committee, eds., Flora of North America North of Mexico. Vol. 28, New York and Oxford, pp. 559-561.

LI, X.-Q., Q. ZUO, M. LI, S. HE, Y. JIA \& Y.-F. WANG. 2015. Phylogenetic relationships and species delimitation among the taxa with propagula in Pseudotaxiphyllum (Plagiotheciaceae, Bryophyta). - Journal of Systematics and Evolution 53(2): 179-190.

SCHOFIELD, W. B. \& H. A. CRUM. 1973. Disjuctions in bryophytes. Annals of the Missouri Botanical Garden 59: 174-202.

SCHOFIELD, W. B. 1988. Bryophyte disjunctions in the Northern Hemisphere: Europe and North America. - Botanical Journal of the Linnean Society 98: 211-224.

Appendix 1. Newly generated sequences [ITS / trnL-F]

Pseudotaxiphyllum distichaceum: Kuril Islands, Kunashir, Ignatov 06-1697 (MHA 9046680) isolate OK2431 [—/ MN849421]; Kuril Islands, Iturup, Fedosov 15-2-183 (MW 9074998) isolate OK2475 [MN847623 / MN849423]. Pseudotaxiphyllum subfalcatum: Kuril Islands, Iturup, Pisarenko op05831 (MW 9060912), isolate OK2474 [MN847622 / ]MN849422]; Buryatia, 9 Aug 2011 Kazanovsky s.n. (MHA), isolate OK2417 [MN847621 / MN849420] 